\title{
Asas Perlindungan Hukum dan Entrustable Professional Activities (EPAs) dalam Proses Kredensial Mahasiswa Dokter Layanan Primer Masa Transisi di Wahana Pendidikan
}

\author{
Erfen Gustiawan Suwangto ${ }^{1}$, Yoni Fuadah Syukriani², Insi Farisa Desy Arya ${ }^{3}$ \\ ${ }^{1}$ Departemen Bioetika dan Hukum Kesehatan, Fakultas Kedokteran dan Ilmu Kesehatan, \\ Universitas Katolik Indonesia Atma Jaya \\ ${ }^{2}$ Departemen Ilmu Kedokteran Forensik dan Medikolegal, Fakultas Kedokteran, Universitas Padjadjaran \\ ${ }^{3}$ Departemen Ilmu Kesehatan Masyarakat, Fakultas Kedokteran, Universitas Padjadjaran
}

\begin{abstract}
Abstrak
Dalam Rancangan Peraturan Pemerintah (RPP) terkait pendidikan Dokter Layanan Primer (DLP), terdapat konsep program Rekognisi Pembelajaran Lampau(RPL) bagi dokter yang telah berpraktik lebih dari lima tahun untuk melalui Pendidikan Masa Transisi selama enam bulan. Hal ini menimbulkan pertanyaan mengenai proses supervisi terhadap peserta didik dalam program singkat ini. Di luar negeri, proses supervisi untuk peserta program spesialis kedokteran mulai dikembangkan dengan program bernama Entrustable Professional Activities (EPAs). Penelitian ini merupakan penelitian yuridis normatif yang bersifat deskriptif berdasarkan analisis data secara kualitatif. Hasil dari penelitian ini adalah deskripsi tentang proses kredensial Mahasiswa Program DLP Masa Transisi di wahana pendidikan, deskripsi asas-asas perlindungan hukum terkait Mahasiswa Program DLP Masa Transisi, dan jawaban bahwa asas perlindungan hukum akan terpenuhi dengan integrasi EPAs ke dalam proses kredensial antara Mahasiswa Program DLP dengan wahana pendidikan. Diskusi penelitian ini adalah tentang gambaran proses kredensial Peserta Program Pendidikan Dokter Spesialis berdasarkan aturan yang telah ada, jika diterapkan bagi Mahasiswa Program DLP Masa Transisi di wahana pendidikan yang memakai EPAs dalam sistem supervisinya, gambaran asas perlindungan hukum yang terkait dengan Mahasiswa Program DLP Masa Transisi, serta menjawab apakah integrasi EPAs dalam proses kredensial Mahasiswa Program DLP Masa Transisi akan memenuhi asas perlindungan hukum bagi mereka.
\end{abstract}

Kata kunci : Perlindungan hukum, Entrusted Professional Activities, Program Dokter Layanan Primer Masa Transisi

\section{Legal Protection Principles and Entrustable Professional Activities in Credential of Primary Care Physician Students in Transition Education Program}

\begin{abstract}
In Indonesia's Regulatory Plan concerning Primary Care Physician (PCP) posgraduate study program, there is a concept of Recognition of Prior Learning (RPL) program for doctors who have practiced more than five years who could join a six months transition education program. This program will establish questions about how to supervise the residents in the short period of time. In other countries, supervision process of the residents is starting to be developed in a program called Entrustable Professional Activities (EPAs). This is a normative juridicial research, descriptive based on qualitative data analysis. The results are description about credential process of PCP students who join transition education program in health centers, description about legal protection principles concerning PCP students who join transition education program, and answer that legal protection principles are going to be fullfilled by integrating EPAs in credential process between PCP residents and teaching health centers. The discussion of this research are description about credential process of other medical specialty residents, based on existing regulations, if the credential is implemented for $P C P$ students who join transition education program in health centers which use EPAs in their supervision system, description about legal principles concerning PCP in transition education program, and answer the question about whether legal protection principles are fullfilled if the EPAs is integrated within credential process.
\end{abstract}

Keywords : legal protection, Entrusted Professional Activities (EPAs), Primary Care Physician of transition education program

Korespondensi:

Erfen Gustiawan Suwangto, dr., Sp. DLP, SH., MH.Kes

Departemen Bioetika dan Hukum Kesehatan, Fakultas Kedokteran dan Ilmu Kesehatan,

Universitas Katolik Indonesia Atma Jaya

Jl. Pluit Raya Nomor 2, Jakarta Utara 14440

Mobile : 082111730906

Email : erfen_gs@yahoo.co.id 


\section{Pendahuluan}

Dalam Rancangan Peraturan Pemerintah (RPP) terkait pendidikan Dokter Layanan Primer (DLP) setara spesialis, terdapat konsep program Rekognisi Pembelajaran Lampau (RPL) bagi dokter yang telah berpraktik lebih dari lima (5) tahun untuk cukup melalui Pendidikan Masa Transisi selama enam (6) bulan berbasis tempat kerja. Hal ini menimbulkan pertanyaan mengenai proses supervisi terhadap peserta didik dalam program singkat ini, terutama di wahana pendidikan seperti Pusat Kesehatan Masyarakat (Puskesmas) yang selama ini belum pernah diterapkan seperti di RS Pendidikan. Di luar negeri, proses supervisi untuk peserta program spesialis kedokteran mulai dikembangkan dengan program bernama Entrustable Professional Activities (EPAs). ${ }^{1,2,3,4}$

Tujuan penelitian ini adalah untuk mendapatkan gambaran proses kredensial Peserta Program Pendidikan Dokter Spesialis berdasarkan aturan yang telah ada, jika diterapkan bagi Mahasiswa Program DLP Masa Transisi di wahana pendidikan yang memakai EPAs dalam sistem supervisinya, mendapatkan gambaran asas perlindungan hukum yang terkait dengan Mahasiswa Program DLP Masa Transisi, serta menjawab apakah integrasi EPAs dalam proses kredensial Mahasiswa Program DLP Masa Transisi akan memenuhi asas perlindungan hukum bagi mereka.

\section{Metode}

Rancangan penelitian ini adalah penelitian yuridis normatif dengan instrumen dokumentasi. Metode pengumpulan data dalam penelitian ini adalah dengan melakukan studi kepustakaan. Namun demikian, karena ada data sekunder yang bersifat privat, maka perlu studi lapangan, tetapi tidak untuk mencari data primer, melainkan untuk mencocokkan data saja. Jenis bahan hukum dalam penelitian ini terdiri dari bahan hukum primer, sekunder, dan tersier.

Metode analisis data penelitian ini dengan metode kualitatif yang menghasilkan data deskriptif. Jenis bahan hukum dalam penelitian ini terdiri dari bahan hukum primer, sekunder, dan tersier. Bahan hukum primer merupakan bahan hukum yang mengikat atau yang membuat orang taat pada hukum seperti peraturan perundangundangan, dan putusan hakim. Bahan hukum primer yang penulis gunakan di dalam penulisan ini, yakni berbagai peraturan perundangan di Indonesia, yaitu Undang-Undang Dasar 1945, UU Nomor 20 Tahun 2003 tentang Sistem Pendidikan
Nasional, UU Nomor 29 Tahun 2004 tentang Praktik Kedokteran, UU Nomor 40 Tahun 2004 tentang Sistem Jaminan Sosial Nasional (SJSN), Undang-Undang Nomor 36 Tahun 2009 tentang Kesehatan, Undang-Undang Nomor 44 Tahun 2009 tentang Rumah Sakit, UU Nomor 12 Tahun 2012 tentang Pendidikan Tinggi, Undang-Undang Nomor 20 Tahun 2013 tentang Pendidikan Kedokteran, UU Nomor 36 Tahun 2014 tentang Tenaga Kesehatan, Peraturan Presiden Nomor 8 Tahun 2012 tentang KKNI (Kerangka Kualifikasi Nasional Indonesia), Peraturan Konsil Kedokteran Indonesia Nomor 12 tahun 2013 tentang Penerapan Kerangka Kualifikasi Nasional untuk Pendidikan Kedokteran (yang juga disinkronkan dengan Trilogi World Federation of Medical Education (WFME) Global Standards for Quality Improvement, Wonca Standards for Postgraduate Family Medicine Education, ARPaC Standards for Training Primary Care Physicians for Asean Region), Peraturan Menteri Kesehatan Nomor 512 Tahun 2007 tentang izin praktik,

Peraturan Menteri Kesehatan Nomor 755 Tahun 2011 Penyelenggaraan Komite Medis di Rumah Sakit. Sedangkan yang dimaksud dengan bahan sekunder disini oleh peneliti adalah doktrin-doktrin yang ada di dalam buku, jurnal hukum, dan internet dalam bidang pendidikan, pelayanan kesehatan, hukum kesehatan, pendidikan kedokteran, dan lain-lain. Sedangkan bahan hukum tersier adalah bahan hukum yang mendukung bahan hukum primer dan bahan hukum sekunder dengan memberikan pemahaman dan pengertian atas bahan hukum lainnya.

\section{Hasil}

Maksud dari Integrasi Entrustable Professional Activities (EPAs) dalam Proses Kredensial Mahasiswa Program Dokter Layanan Primer Masa Transisi dengan Wahana Pendidikan sebagai Bentuk Perlindungan Hukum.

Pasal 31 Ayat (1) poin a UU Pendidikan Kedokteran berbunyi demikian, " Setiap Mahasiswa berhak memperoleh perlindungan hukum dalam mengikuti proses belajar mengajar, baik di Fakultas Kedokteran atau Fakultas Kedokteran Gigi maupun di Rumah Sakit Pendidikan dan Wahana Pendidikan Kedokteran"

Pasal 31 Ayat (3) UU Pendidikan Kedokteran juga berbunyi demikian, "Ketentuan lebih lanjut mengenai hak dan kewajiban Mahasiswa sebagaimana dimaksud pada Ayat (1) dan Ayat (2) diatur dalam Peraturan Menteri."

Hal ini berarti Mahasiswa Program Dokter Layanan Primer termasuk yang mengikuti 
Pendidikan Masa Transisi selama enam (6) bulan, berhak atas jaminan hak asasi di seluruh tahap pendidikannya walaupun belum diatur secara eksplisit tentang tahapan tersebut, termasuk bagaimana tahapan ketika magang di Puskesmas. Perlindungan hukum ini dapat terealisasi karena pendidik yang melakukan supervisi (pengawasan) dalam proses EPAs akan mengkonfirmasi bahwa peserta didik telah mencapai tingkat di mana mereka telah dapat dipercayakan untuk melakukan suatu aktivitas tanpa supervisi langsung setelah melalui beberapa tahap yang jelas. ${ }^{2,3,4}$ Oleh sebab itu, perlindungan hukum bukan hanya bagi pasien, tetapi juga bagi semua pihak, termasuk dokter dan mahasiswa kedokteran demi prinsip keadilan yang menjadi salah satu asas hukum utama. $5,6,7$

Dasar hukum bagi integrasi Entrustable Professional Activities (EPAs) dalam proses kredensial Mahasiswa Program Dokter Layanan Primer Masa Transisi.

Berdasarkan kajian dalam penelitian ini, landasan hukum bagi perlindungan hukum Mahasiswa Program Dokter Layanan Primer Masa Transisi dalam memberikan pelayanan kesehatan seharusnya adalah: Undang-Undang Dasar 1945, UU Nomor 20 Tahun 2003 tentang Sistem Pendidikan Nasional, UU Nomor 29 Tahun 2004 tentang Praktik Kedokteran, UU Nomor 40 Tahun 2004 tentang Sistem Jaminan Sosial Nasional (SJSN) yang mementingkan dokter layanan primer untuk kendali mutu dan kendali biaya, UU Nomor 36 Tahun 2009 tentang Kesehatan, UU Nomor 44 Tahun 2009 tentang Rumah Sakit, UU Nomor 12 Tahun 2012 tentang Pendidikan Tinggi, UU Nomor 20 Tahun 2013 tentang Pendidikan Kedokteran, UU Nomor 36 Tahun 2014 tentang Tenaga Kesehatan (berlaku lex posterior), Peraturan Presiden Nomor 8 Tahun 2012 tentang KKNI (Kerangka Kualifikasi Nasional Indonesia), Peraturan Konsil Kedokteran Indonesia Nomor 12 tahun 2013 tentang Penerapan Kerangka Kualifikasi Nasional untuk Pendidikan Kedokteran, yang juga disinkronkan dengan Trilogi World Federation of Medical Education (WFME) Global Standards for Quality Improvement, Wonca Standards for Postgraduate Family Medicine Education, $A R P a C$ Standards for Training Primary Care Physicians for Asean Region, Peraturan Menteri Kesehatan Nomor 2052 Tahun 2011 tentang Izin Praktik dan Pelaksanaan Praktik Kedokteran, Peraturan Menteri Kesehatan Nomor 755 Tahun 2011 Penyelenggaraan Komite Medis di Rumah Sakit.

Mengingat banyak peraturan yang harusnya dibuat terlebih dahulu terkait dengan pelayanan kesehatan oleh Mahasiswa Program Dokter
Layanan Primer Masa Transisi, maka harus dibentuk kolegium di bawah organisasi profesi (Ikatan Dokter Indonesia) yang berhak mengampu keilmuan dari Mahasiswa Program Dokter Layanan Primer Masa Transisi sesuai UU Praktik Kedokteran. Perihal kolegium berada di bawah organisasi profesi juga sedang digugat ke Mahkamah Konstitusi karena lazimnya di dunia internasional, kolegium biasanya berada langsung di bawah konsil kedokteran.

Pembentukan kolegium tersebut juga harus diikuti penerapan hospital by law dan staff medic by law yang telah diatur dalam Peraturan Menteri Kesehatan Nomor 631 Tahun 2005 tentang Pedoman Peraturan Internal Staf Medis di Rumah Sakit (Medical Staff by Laws). Hospital by law dan staff medic by law adalah dua hal yang harus diperkuat apabila peraturan teknis mengenai Program Dokter Layanan Primer Masa Transisi ini belum dibuat.

Rancangan Peraturan Pemerintah terkait Dokter Layanan Primer juga sedang dibuat dan belum dapat dijadikan sebagai dasar hukum.

Sebagai catatan penting dalam penelitian ini, khusus untuk wahana pendidikan bahkan belum ada peraturan yang dapat dijadikan dasar hukum bagi mahasiswa kedokteran manapun, termasuk bagi Mahasiswa Program Dokter Layanan Primer Masa Transisi. Lebih jauh lagi, UU Pendidikan Kedokteran tidak memerintahkan pembuatan peraturan teknis tentang wahana pendidikan sehingga butuh peraturan teknis yang bersifat diskresi dari pemerintah (dalam hal ini diwakili oleh Menteri Kesehatan) untuk membuat aturan teknis khusus terkait wahana pendidikan untuk Mahasiswa Dokter Layanan Primer (termasuk untuk Mahasiswa Program Dokter Layanan Primer Masa Transisi). Pengaturan wahana pendidikan termasuk penerapan hospital by law dan staff medic by law di wahana pendidikan seperti Puskesmas bertujuan agar Mahasiswa Program Dokter Layanan Primer Masa Transisi dapat melakukan proses kredensial dengan wahana pendidikan untuk kemudian mendapatkan kewenangan klinis dan penugasan klinis sehingga terlindungi secara hukum, seperti pengaturan yang telah dilakukan di RS pendidikan.

Bentuk pengaturan integrasi Entrustable Professional Activities (EPAs) dalam proses kredensial Mahasiswa Program Dokter Layanan Primer Masa Transisi.

Oleh karena Program Dokter Layanan Primer Masa Transisi ini setara spesialis, maka aturan perlindungan hukum bagi Mahasiswa Program Dokter Layanan Primer seharusnya mirip dengan aturan perlindungan hukum untuk Peserta Pendidikan Dokter Spesialis (PPDS). Namun, pola perlindungan hukum untuk PPDS 
ini hanya dapat diterapkan jika nanti diatur dalam peraturan teknis yang terpisah karena Program Dokter Layanan Primer adalah setara spesialis, bukan spesialis, apalagi hanya dijalani selama enam (6) bulan. Aturan teknis perlindungan hukum ini pun hanya dapat diterapkan apabila permasalahan landasan hukum dan cita hukum UU Pendidikan Kedokteran juga telah diselesaikan. Jika permasalahan-permasalahan tersebut telah diselesaikan, maka aturan tentang perlindungan hukum bagi Mahasiswa Program Dokter Layanan Primer Masa Transisi dapat disesuaikan dengan aturan perlindungan hukum Peserta Program Dokter Spesialis (PPDS) atau residen yang selama ini telah ada.

Dengan sistem kredensial seperti PPDS, tindakan medis hanya boleh dilakukan oleh dokter yang kompeten. Dengan demikian, perlu ditentukan terlebih dahulu kompetensi Mahasiswa Program Dokter Layanan Primer Masa Transisi oleh Kepala Program Studi (KPS), kemudian baru ditentukan clinical privilege (kewenangan klinis) dan clinical appointment (penugasan klinis) oleh komite medis RS pendidikan. Hal ini belum diatur untuk wahana pendidikan sehingga dapat disesuaikan dengan aturan yang telah ada untuk RS Pendidikan. Proses kredensial tersebut bertujuan demi keselamatan pasien (patient safety), yang terdiri dari komponen good clinical governance, risk management (manajemen risiko), dan quality improvement (perbaikan kualitas) di wahana pendidikan seperti Puskesmas. $8,9,10,11,12$

Jika EPAs diintegrasikan dalam proses kredensial terkait kewenangan klinis dan penugasan klinis Mahasiswa Program Dokter
Layanan Primer Masa Transisi di wahana pendidikan seperti Puskesmas, maka dapat memperjelas perlindungan hukum bagi mereka. Perlindungan hukum ini dapat terealisasi karena pendidik yang melakukan supervisi (pengawasan) dalam proses EPAs akan mengkonfirmasi bahwa peserta didik telah mencapai tingkat di mana mereka telah dapat dipercayakan untuk melakukan suatu aktivitas tanpa supervisi langsung setelah melalui beberapa tahap yang jelas. ${ }^{2,3,4}$ Tahapan supervisi tersebut terdiri dari lima (5) tahap, antara lain:

Mahasiswa Program Dokter Layanan Primer Masa Transisi hanya melakukan observasi (tapi bukan eksekusi), walau tanpa supervisi; Mahasiswa Program Dokter Layanan Primer Masa Transisi melakukan eksekusi dengan supervisi langsung oleh pengawas secara proaktif; Mahasiswa Program Dokter Layanan Primer Masa Transisi melakukan eksekusi dengan supervisi reaktif oleh pengawas (supervisi dilakukan jika diminta oleh Mahasiswa Program Dokter Layanan Primer Masa Transisi dan dapat segera dilakukan oleh pengawas jika dibutuhkan); Mahasiswa Program Dokter Layanan Primer Masa Transisi diawasi oleh pengawas pada pada rentang jarak tertentu saja dan atau hanya melakukan supervisi terhadap hasil kerja Mahasiswa Program Dokter Layanan Primer Masa Transisi (secara umum dapat dikatakan bahwa Mahasiswa Program Dokter Layanan Primer Masa Transisi tidak harus disupervisi lagi); Supervisi yang dilakukan Mahasiswa Program Dokter Layanan Primer Masa Transisi senior kepada juniornya ${ }^{6}$

Kepercayaan yang diberikan secara bertingkat secara formal menyatakan bahwa peserta

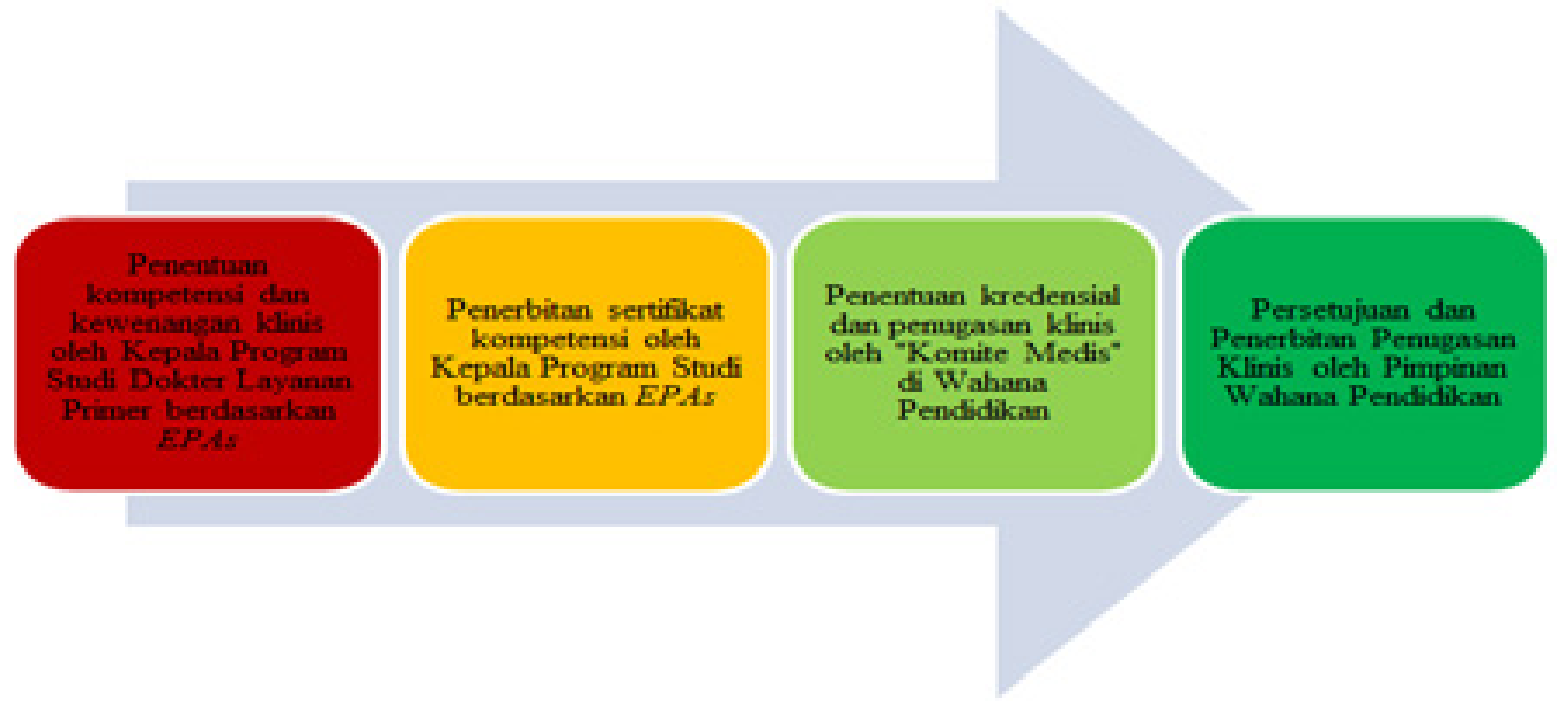

\section{Gambar 1 Rekomendasi alur proses kredensial Mahasiswa Program Dokter Layanan Primer} Masa Transisi 
didik telah layak untuk dikurangi supervisinya dalam bentuk sertifikat yang disebut STAR (Statement of Awarded Responsibility) dan harus didokumentasikan secara seksama. ${ }^{13}$ Berikut adalah rekomendasi proses kredensial-clinical privilege-clinical appointment-medical liability bagi Mahasiswa Program Dokter Layanan Primer Masa Transisi di wahana pendidikan jika mengacu pada Program Pendidikan Dokter Spesialis yang selama ini telah dilakukan (Gambar 1).

\section{Tabel 1 Rekomendasi tahapan supervisi Mahasiswa Dokter Layanan Primer Masa Transisi}

\begin{tabular}{|c|c|c|}
\hline $\begin{array}{c}\text { Tahap } \\
\text { Pendidikan } \\
\text { Program DLP } \\
\text { Masa Transisi }\end{array}$ & $\begin{array}{c}\text { Supervisi } \\
\text { Mahasiswa } \\
\text { Program DLP } \\
\text { Masa Transisi }\end{array}$ & $\begin{array}{c}\text { Penempatan } \\
\text { Mahasiswa } \\
\text { Program DLP } \\
\text { Masa Transisi }\end{array}$ \\
\hline Tahap dasar & $\begin{array}{l}\text { Supervisi } \\
\text { penuh }\end{array}$ & RS pendidikan \\
\hline $\begin{array}{l}\text { Tahap } \\
\text { menengah }\end{array}$ & $\begin{array}{l}\text { Masih } \\
\text { membutuhkan } \\
\text { supervisi }\end{array}$ & $\begin{array}{l}\text { RS pendidikan } \\
\& \text { wahana } \\
\text { pendidikan }\end{array}$ \\
\hline $\begin{array}{l}\text { Tahap akhir } \\
\text { (tahap mandiri) }\end{array}$ & $\begin{array}{l}\text { Supervisi jarak } \\
\text { jauh dengan } \\
\text { teknologi yang } \\
\text { baik }\end{array}$ & $\begin{array}{l}\text { Dapat } \\
\text { ditempatkan di } \\
\text { RS dan wahana } \\
\text { pendidikan } \\
\text { lain dengan } \\
\text { tanggung jawab } \\
\text { hukum secara } \\
\text { penuh }\end{array}$ \\
\hline
\end{tabular}

Ada beberapa catatan terkait rekomendasi tahapan supervisi Mahasiswa Dokter Layanan Primer Masa Transisi pada Tabel 2 di atas, antara lain:

Tahapan ini dapat langsung dilewatkan jika dalam Pendidikan Masa Transisi, Mahasiswa DLP Masa Transisi lolos proses Rekognisi Pembelajaran Lampau sehingga dapat langsung diberikan sertifikat kompetensi.; Jika belum ada kompetensi yang dapat direkognisi, dapat diberikan pelatihan khusus sampai semua kompetensi tercapai (ada kemungkinan harus lebih dari 6 bulan atau harus ikut program reguler selama 3 tahun atau program pembelajaran berkelanjutan yang diikuti bertahap tiap 5 tahun dengan peningkatan kompetensi khusus tertentu yang diakui oleh Konsil Kedokteran Indonesia).; Jika kompetensi sebagian ada yang sudah ada yang tercapai dan ada sebagian yang tidak, maka dapat diberikan sertifikat kompetensi khusus untuk kompetensi yang sudah tercapai saja sehingga tidak menghambat tindakan medis mahasiswa yang sudah bekerja di tempat kerjanya masing-masing.

Dengan kata lain, butuh fleksibilitas seperti payung hukum tentang Hospital bylaw di Rumah Sakit

Asas-Asas Perlindungan Hukum bagi Integrasi Entrustable Professional Activities (EPAs).

Berdasarkan pengertian asas perlindungan hukum dalam literatur, maka asas perlindungan

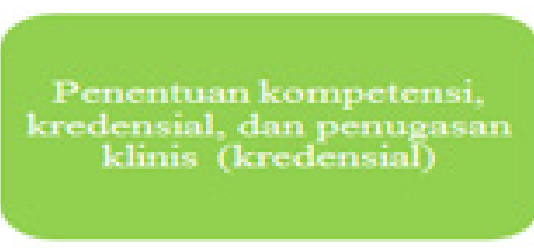

Penentuan penempatan Mahasiswa Dokter

Layanan Primer Masa Transisi

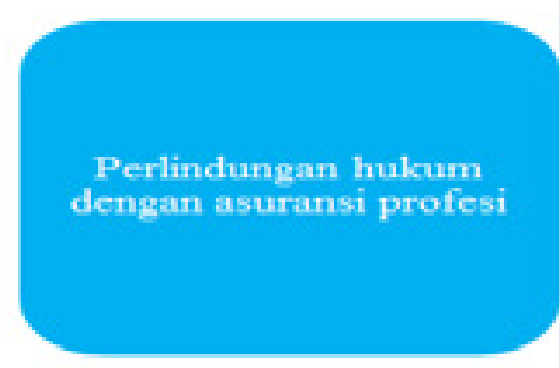

- Mahasiswa Program DLP Masa Transisi yang ditempatkan di daerah terpencil harus disupervisi periodik

Penentuan kompetensi, kredensial, dan penugasan klinis di wahana pendidikan

\section{Gambar 2 Rekomendasi rangkuman alur tahapan perlindungan hukum bagi Mahasiswa Program Dokter Layanan Primer Masa Transisi}

- Penempatan Mahasiswa Program DLP Masa Transisi tahap akhir (mandiri) yang ditentukan oleh Kepala Program Studi (KPS) berdasarkan EPAs ditempatkan di daerah tespencil harus dilindungi bupati/walikota, dekan, dan pimpinan wahana pendidikan sepengetahuan DPRD. Nota kesepahaman tersebut harus berisi tentang insentif, asturansi profesi dan bantuan hukam bagi Mahasiswa Program DL.P Masa Transisi

- Di daerah terpencil, Mahasiswa Program DLP Masa Transisi kadang harus melakukan tindakan medis di haar kompetensinya yang harus disetujui oleh Kepala Program Studi 
hukum bagi pengaturan Mahasiswa Program Dokter Layanan Primer Masa Transisi adalah dasar (sesuatu yg menjadi tumpuan berpikir atau berpendapat), dasar cita-cita, hukum dasar bagi perlindungan hukum Mahasiswa Program Dokter Layanan Primer Masa Transisi dalam memberikan pelayanan kesehatan. ${ }^{14}$

Banyak hal yang diatur dalam UU Pendidikan Kedokteran ini, tetapi sesuai dengan pembatasan masalah dalam penelitian ini, maka selanjutnya hanya akan dikaji hal khusus terkait cita kepastian hukum mengenai perlindungan hukum untuk Mahasiswa Program Dokter Layanan Primer Masa Transisi dalam memberikan pelayanan kesehatan.

Asas kepastian hukum otomatis akan menjadi salah satu dasar bagi perlindungan hukum bagi Mahasiswa Program Dokter Layanan Primer Masa Transisi dalam memberikan pelayanan kesehatan, mengingat penelitian penelitian ini sebelumnya bahwa asas kepastian hukum adalah asas dasar dalam perundang-undangan yang baik, bahkan termasuk salah satu asas dalam pelayanan kesehatan adalah asas legalitas (landasan yuridis). Dalam hal ini, dari sisi asas kepastian hukum, salah satu aspek yang harus dikaji adalah apakah Mahasiswa Program Pendidikan Dokter Layanan Primer Masa Transisi dapat atau tidak dapat berpraktik secara legal semasa pendidikan.

Dari pembahasan tersebut $\mathrm{di}$ atas, asas kepastian hukum tentang perlindungan hukum bagi pengaturan Mahasiswa Program Dokter Layanan Primer Masa Transisi dalam memberikan pelayanan kesehatan yang diatur dalam Pasal 31 UU Pendidikan Kedokteran, dapat dikaji dengan: Asas lex superior derogat legi inferior yang artinya apakah Pasal 31 UU Pendidikan Kedokteran ini adalah peraturan yang lebih tinggi menyampingkan yang rendah (asas hierarki) atau bahkan berada di bawah UU yang lain.; Asas lex specialis derogat legi generali, yaitu asas penafsiran hukum yang menyatakan bahwa Pasal 31 UU Pendidikan Kedokteran yang bersifat khusus (lex specialis) menyampingkan UU lain yang bersifat umum (lex generalis).; Asas lex posterior derogat legi priori, yaitu pada peraturan yang sederajat, peraturan yang paling baru. Dalam hal ini, harus dikaji apakah Pasal 31 UU Pendidikan Kedokteran melumpuhkan peraturan yang lama atau bahkan dilumpuhkan oleh peraturan yang lebih baru).; Asas legalitas, yaitu bahwa Pasal 31 UU Pendidikan Kedokteran tidak dapat berlaku surut. ${ }^{15,16}$

Dari pembahasan subjudul-subjudul sebelumnya, didapatkan bahwa maksud ketentuan Pasal 31 terkait perlindungan hukum bagi Mahasiswa Program Dokter Layanan Primer belum memenuhi asas kepastian hukum itu semua, apalagi yang terkait integrasi Entrustable Professional Activities (EPAs) dalam proses kredensial Mahasiswa Program Dokter Layanan Primer Masa Transisi dengan wahana pendidikan sebagai perlindungan hukum dalam memberikan pelayanan kesehatan. Oleh karena itu, butuh sinkronisasi berbagai peraturan-perundangan yang ada dengan UU Pendidikan Kedokteran, penyelesaian aturan-aturan teknis yang ada, lalu dibuat peraturan teknis mengenai integrasi Entrustable Professional Activities (EPAs) dalam proses kredensial Mahasiswa Program Dokter Layanan Primer Masa Transisi dengan wahana pendidikan sebagai perlindungan hukum dalam memberikan pelayanan kesehatan sesuai rekomendasi pembahasan sebelumnya.

Asas keadilan dan manfaat dapat terpenuhi dalam integrasi Entrustable Professional Activities (EPAs) dalam proses kredensial Mahasiswa Program Dokter Layanan Primer Masa Transisi dengan wahana pendidikan jika perlindungan hukum bagi Mahasiswa Program Dokter Layanan Primer dalam pelayanan kesehatan telah memenuhi cita kepastian hukum. Jika tidak ada jaminan tentang kepastian hukumnya, otomatis tidak ada jaminan tentang keadilan dan kemanfaatan dalam Program Mahasiswa Program Dokter Layanan Primer dalam pelayanan kesehatan, termasuk terkait mengenai perlindungan hukum bagi mereka. Selain asas-asas umum yang telah dibahas di atas, maka asas perlindungan hukum bagi Mahasiswa Dokter Layanan Primer Masa Transisi dalam pelayanan kesehatan melalui integrasi EPAs dalam proses kredensial di wahana pendidikan, juga dapat berisi asas-asas lain sesuai dengan penelitian penelitian ini sebelumnya. Asas-asas tersebut antara lain asas pendidikan kedokteran, asas praktik kedokteran, dan lain-lain. Oleh karena maksud ketentuan integrasi Entrustable Professional Activities (EPAs) dalam proses kredensial Mahasiswa Program Dokter Layanan Primer Masa Transisi dengan wahana pendidikan belum memenuhi asas-asas umum tersebut di atas, maka asas-asas khusus terkait dengan pendidikan kedokteran dan praktik kedokteran di dalam berbagai peraturan perundangan lain juga belum tercapai, kecuali harmonisasi peraturan perundangan dan penyelesaian aturan teknis telah dilakukan seperti rekomendasi dalam pembahasan sebelumnya.

\section{Pembahasan}

Berdasarkan tahap hasil penelitian dan pembahasan dalam penelitian ini, perlindungan hukum bagi Mahasiswa Program Dokter Layanan 
Primer Masa Transisi dengan mengintegrasikan EPAs dalam kredensial pelayanan kesehatan di wahana kesehatan, hendaknya dimulai dari kajian terhadap asas hukum secara umum, termasuk perundang-undangan yang baik, serta asasasas khusus dalam pendidikan dan pelayanan kesehatan terhadap integrasi Entrustable Professional Activities (EPAs) dalam proses kredensial Mahasiswa Program Dokter Layanan Primer Masa Transisi dengan wahana pendidikan sebagai perlindungan hukum dalam memberikan pelayanan kesehatan. Dari hasil penelitian dan pembahasan dalam penelitian ini, perlindungan hukum bagi Mahasiswa Program Dokter Layanan Primer Masa Transisi dalam pelayanan kesehatan sebagaimana dimaksud pasal $31 \mathrm{UU}$ Pendidikan Kedokteran, belum memenuhi asas hukum umum, termasuk asas-asas hukum umum (termasuk asas perundang-undangan yang baik), sehingga otomatis belum memenuhi asas-asas khusus pendidikan dan pelayanan kesehatan. Akan tetapi, jika semua permasalahan tersebut telah teratasi, EPAs dapat menjadi salah satu alternatif perlindungan hukum bagi Mahasiswa Program Dokter Layanan Primer Masa Transisi. Saran penelitian ini adalah bahwa perlindungan hukum dalam hal tersebut di atas hanya dapat diterapkan jika nanti diatur dalam peraturan teknis yang jelas, serta perlunya fleksibilitas proses kredensial untuk tiap jenis kompetensi spesifik jika peserta didik membutuhkannya segera untuk bekerja walau pendidikan masa transisi belum berakhir.

\section{Daftar Pustaka}

1. ten Cate O.2005. Entrustability of professional activities and competencybased training. Med Educ 39(12):1176-1177.

2. Shaughnessy AF, Sparks J, Cohen-osher M, Goodell KH, Sawin GL, Gravel J. 2013. Entrustable professional activities in family medicine. J Grad Med Educ 5(1):112-118.

3. Englander R, Flynn T, Call S, Carraccio C, Cleary L, Fulton T,Garriry M, Lieberman S, Lindeman B, Lypson ML, et al. 2014. Core entrustable professional activities for entering residency - Curriculum developers guide. Washington DC. [Accessed 3 July 2015] Retrieved from www.aame.org by: Available through MedEdPortal.org

4. ten Cate O. 2013. Nuts and bolts of entrustable professional activities. J Grad Med Educ 5(1):157-158
5. Philipus M. Hadjon, 1987, Perlindungan Hukum Bagi Rakyat Di Indonesia Sebuah Studi tentang Prinsip-Prinsipnya, Penanganannya Oleh Pengadilan Dalam Lingkungan Peradilan Umum dan Pembentukan Peradilan Administrasi Negara, Surabaya: PT Bina Ilmu, hal. 49

6. Satjipto Raharjo, 1993, Penyelenggaraan Keadilan dalam Masyarakat yang Sedang Berubah, Jurnal Masalah Hukum

7. CST Kansil, 1989, Pengantar Ilmu Hukum dan Tata Hukum Indonesia, Jakarta: Balai Pustaka

8. Budi Sampoerna. Pertanggungjawaban hukum / medical liability system dikaitkan dengan peran residen, fakultas kedokteran dan RS pendidikan. Semiloka Nasional Pendidikan Dokter Spesialis dan Peran Dokter Layanan Primer. Jakarta: April 2013.

9. Choo KJ, Arora VM, Barach P, Johnson JK, Farnan JM. 2014. How do supervising physicians decide to entrust residents with unsupervised tasks? A qualitative analysis. J Hosp Med 9(3):169-175.

10. ten Cate O. 2006. Trust, competence, and the supervisor's role in postgraduate training. BMJ 333(7571):748-751.

11. Schultz K, Griffiths J, Lacasse M. 2015. The application of entrustable professional activities to inform competency decisions in a family medicine residency program. Acad Med 90:888-897.

12. Sterkenburg A, Barach P, Kalkman C, Gielen M, ten Cate O. 2010. When do supervising physicians decide to entrust residents with unsupervised tasks? Acad Med 85(9):14081417

13. ten Cate O, Scheele F. 2007. Competencybased postgraduate training: Can we bridge the gap between theory and clinical practice? Acad Med 82(6):542-547

14. Tim Redaksi KBBI PB. 2008. Kamus Besar Bahasa Indonesia. Ed. IV. Pendidikan Nasional.

15. Ishaq, Dasar-dasar Ilmu Hukum, Sinar Grafika, 2007, hal. 76

16. Purnadi Purbacaraka dan Soerjono Soekanto, Peraturan perundang-undangan dan Yurisprudensi, Bandung: PT. Citra Aditya Bakti, 1989, Edisi III, hal.7-11 